\title{
ANALISIS PENGAMBILAN KEPUTUSAN INVESTASIUNTUK MERAIH PROFIT KONSISTEN PADA PASAR UANG ONLINE
}

\author{
Prasetya Tri Mahendra \\ STIE PGRI Nganjuk
}

\begin{abstract}
The continued development of information technology to encourage various parties to compete in fulfilling the needs of both physical and non-physical. Market as the fulfillment of human needs from the first until now always been growing rapidly, ranging from market goods, services market, the labor market to the capital market and money market. Exchange or money market is still very dominate the world market, as technological developments for today's financial markets can be done with the online system, plus the application of the concept of sharia / non usury / interest for the non-Muslim perpetrators of the majority in Indonesia. Corresponding description of the background in front of which has been delivered, we can formulate the problem of this research, namely: How good decision making in investment to get a consistent profit on the internet online money market trading? By using both Technical Analysis / mathematical analysis and supported by fundamentals, then investing in a money market alternative benefit / profit in addition to the public revenue. Besides, the application of the business need for mentors, to provide training online currency trading. Because they factor of trading psychology and money management is also a major thing for critical success trading these currencies online.
\end{abstract}

Keyword : Investment, consistent profit, online money market trading

\section{PENDAHULUAN}

\section{LATAR BELAKANG}

Semakin berkembangnya teknologi informasi mendorong berbagai pihak untuk berlomba dalam pemenuhan kebutuhan baik secara fisik maupun non-fisik. Pemenuhan kebutuhan manusia memang tidak akan pernah ada batasannya kerena sifat dasar manusia yang selalu ingin berkembang dari waktu ke waktu.

$$
\text { Pemenuhan ekonomi, }
$$

khususnya secara financial atau keuangan mendorong manusia pada era sekarang untuk meningkatkan kualitas dan kuantitas dirinya agar berharga dan dihargai dengan nilai tukar yang tinggi, meskipun pada beberapa kalangan nilai ini tidak harus bernilai material, akan tetapi minimal dapat memenuhi kebutuhan hidupnya dalam keseharian dan dapat bermanfaat untuk lingkungan sekitarnya.

Pasar sebagai tempat pemenuhan kebutuhan manusia dari dahulu hingga sekarang selalu berkembang dengan pesat, mulai dari pasar barang, pasar jasa, pasar tenaga kerja hingga pasar modal dan pasar uang. Pada perkembangan teknologi saat ini penulis akan menyajikan bagaimana pasar uang berpengaruh di seluruh dunia baik secara nyata maupun maya, atau lebih dikenal dengan sistem online.

Di Indonesia, perputaran transaksi keuangan lebih didominasi oleh perbankan maupun koperasi yang ada dibawah naungan Bank Indonesia sabagai Induk dari 
kegiatan perbankan tersebut. Lewat Pengawasan dan Kontrol Menteri Keuangan, Bank Indonesia, Menteri Perdagangan dan lantai bursa kegiatan pasar uang berkembang di Indonesia. Dikarenakan pasar uang berhubungan dengan mata uang luar negeri maka dengan sendirinya transaksi ini selalu berkait dengan nilai tukar atau kurs dari beberapa Negara dengan Negara Indonesia. Misalkan untuk transaksi penukaran mata uang asing bagi Tenaga Kerja Luar Negeri ataupun Tenaga Kerja Indonesia, maka secara nyata setiap bank yang ada menyediakan kurs masing-masing Negara dengan kurs rupiah di Indonesia.

Pertukaran atau pasar uang pada contoh diatas sampai sekarang masih digunakan, seiring perkembangan teknologi pasar uang untuk saat ini sudah bisa dilakukan dengan sistem online, atau dengan media internet maka setiap orang dapat melakukan transaksi di pasar uang dunia tanpa harus pergi keluar negeri. Jelas hal ini memudahkan dan dapat dijadikan sebagai mata pencaharian bagi sebagian kalangan yang sudah mengenalnya. Karena merupakan transaksi maya/online maka ada berbagai kebijakan pemerintah baik dalam maupun luar negeri yang menjadi kontrol maupun pengawasan/regulator terhadap halhal yang ada di pasar uang ini, seperti BAPEPAM (Badan Pengawas Pasar Modal) dibawah Kementerian Keuangan dan BAPPEBTI (Badan Pengawas Perdagangan Berjangka Komoditi) dibawah Kementerian Perindustrian dan Perdangan untuk dalam negeri/Indonesia; dan FSA (Financial Services Authority / UK, Inggris), CFTC/NFA (Commodity Future Trading Commission/National Future Association / US, Amerika),
ASIC (Australian Securities and Investment Commission / Australia), FCA (Financial Conduct Authority / UK, Inggris) untuk regulator luar negeri.

Kondisi Indonesia yang mayoritas beragama Islam, dalam penerapan bisnis ini tentu saja akan melibatkan lembaga Negara seperti MUI (Majelis Ulama Indonesia) sebagai regulasi atau kontrol dalam pelaksanaannya. Seperti halnya perbankan syariah, bisnis inipun menerapkan sistem syariah Islam dalam menjalankannya, seperti aturan non-bunga/riba/swap yang salah satu poin utama pembeda bisnis syariah dan konvensional untuk saat ini, disamping adanya akad dan aturan-aturan lain yang disesuaikan dengan prinsip syariah Islam.

\section{RUMUSAN MASALAH}

Sesuai uraian latar belakang yang telah disampaikan didepan, dapat kita rumuskan permasalahan dari penelitian ini, yaitu : Bagaimana pengambilan keputusan yang baik dalam investasi untuk mendapatkan profit yang konsisten pada perdagangan dipasar uang online internet?

\section{TUJUAN PENELITIAN}

Berasarkan rumusan masalah tersebut di atas, maka tujuan penelitian adalah untuk menganalisis pengambilan keputusan yang baik untuk mendapatkan profit / keuntungan yang konsisten pada perdagangan dipasar uang online internet.

\section{MANFAAT PENELITIAN}

1. Bagi Masyarakat

\begin{tabular}{lrr}
\multicolumn{2}{c}{ Penelitian ini } & dapat \\
sebagai & referensi & dan
\end{tabular}


pertimbangan bagi masyarakat luas untuk dapat berinvestasi secara aman dengan tingkat keuntungan yang leih besar daripada hanya disimpan di bank atau dapat sebagai alternatif/pokok pendapatan bagi yang sudah berkerja ataupun yang masih penggangguran.

2. Bagi Lembaga

Bagi STIE Nganjuk, penelitian ini dapat sebagai literatur dan referensi pelengkap sarana publikasi.

3. Bagi Peneliti

Dapat memberikan tambahan pengetahuan dan ketrampilan dalam penulisan penelitian ilmiah serta sebagai sarana untuk peningkatan performance / kinerja peneliti dalam kegiatan kerjanya.

\section{KAJIAN TEORI \\ PASAR UANG}

Definisi Pasar Uang

Sebelum kita membahas tentang pasar uang, terlebih dahulu kita definisikan arti dari uang. Uang adalah segala sesuatu yang dapat dipakai/diterima untuk melakukan pembayaran, baik barang, jasa maupun hutang. Sedangkan fungsi dari uang terdiri dari :

a. Sebagai Satuan Pengukur Nilai

Dengan fungsi ini maka nilai suatu barang/jasa dapat diukur dan dibandingkan. Di Indonesia misalnya, satuan pengukur nilai barang dan jasa yang diperdagangkan dipasar adalah Rupiah.

b. Sebagai Alat Tukar Menukar Keputusan untuk membeli dan menjual dipisahkan oleh fungsi ini. Adanya uang sebagai alat di dalam tukar menukar dapat menghilangkan perlunya ada kesamaan keinginan harus ada terlebih dahulu untuk terjadinya tukar menukar barang dengan barang.

c. Sebagai Alat Penimbun Kekayaan

Uang merupakan salah satu bentuk kekayaan yang dimiliki seseorang selain barang seperti emas, mobil, surat berharga dan lain-lain. Sehingga orang dapat menyimpan kekayaannya dalam bentuk uang.

Pasar uang adalah tempat bertemunya penawaran akan uang dan permintaan akan uang. Penawaran uang ialah jumlah uang yang beredar (JUB) yang ditentukan oleh Pemerintah dan Lembaga Keuangan dengan kebijaksanaan tertentu. Sedangkan Permintaan uang ada 2 (dua) teori yang bisa digunakan, yaitu Kaum Klasik dan Teori Keynes. Kaum Klasik mempunyai teori tentang permintaan uang yang dikenal dengan Teori Kuantitas, yang menyatakan bahwa motivasi masyarakat untuk memegang uang tunai adalah hanya untuk melakukan transaksi tukarmenukar antar mereka dan untuk berjaga-jaga. Sedangkan menurut Keynes, motivasi masyarakat untuk memegang uang selain dua hal diatas (teori kuantitas), ditambah satu lagi keinginan yaitu untuk ber-spekulasi dengan tingkat bunga atau bagi hasil di masa yang akan datang. adalah $\begin{array}{cr}\text { Pasar Uang (Money } & \text { Market) } \\ \text { mekanisme untuk }\end{array}$ memperdagangkan dana jangka pendek, yaitu dana berjangka waktu kurang dari satu tahun. Kegiatan dipasar uang ini terjadi karena ada dua pihak, pihak pertama yang kekurangan dana yang sifatnya jangka pendek, pihak kedua memiliki kelebihan dana dalam waktu jangka 
pendek juga. Mereka itu dipertemukan dipasar uang, sehingga unit yang kekurangan memperoleh dana yang dibutuhkan, sedangkan unit yang kelebihan memperoleh penghasilan atas uang yang berlebih tersebut.

Dalam praktik pasar uang konvensional, yang ditransaksikan adalah hak untuk menggunakan uang dalam jangka waktu tertentu. Jadi dipasar tersebut terjadi transaksi pinjam meminjam dana, yang selanjutnya menimbulkan utangpiutang. Adapun barang yang ditransaksikan dalam pasar ini adalah secara kertas berupa surat utang atau janji untuk membayar sejumlah uang tertentu pada waktu tertentu pula.

Dari segi Islam, pasar uang syariah merupakan mekanisme yang memungkinkan lembaga keuangan syariah untuk menggunakan instrumen pasar dengan mekanisme yang sesuai dengan prinsip syariah baik untuk mengatasi persoalan kekurangan likuiditas maupun kelebihan likuiditas. Hanya saja harus diakui saat ia masih sangat dibutuhkan pengembangan pasar uang berbasis syariah.

Funsi pasar uang secara tidak langsung sebagai sarana pengendali moneter oleh penguasa moneter dalam melaksanakan operasi pasar terbuka dan berfungsi sebagai informasi dimana pasar uang dapat memberikan informasi bagi perusahaan, pemerintah, masyarakat, perorangan, sektor luar negeri, dan peserta pasar uang lainnya mengenai kondisi moneter, preferensi dan tingkah laku pasar uang, pengaruh kebijakan moneter serta pengaruh dari interaksi kegiatan ekonomi dalam dan luar negeri.

\section{Pedagangan di Pasar Uang}

Perdagangan Mata Uang

lewat Pasar Uang, biasa disebut sebagai Foreign Exchange (disingkat Forex) atau dalam bahasa Indonesia biasa disebut Valas (Valuta Asing), merupakan suatu jenis transaksi yang memperdagangkan mata uang (currency) suatu negara terhadap mata uang Negara lainnya. Perdagangan dan transaksi forex bisa dilakukan melalui online ataupun offline. Untuk perdagangan melalui online/internet biasanya dilakukan dengan melalui suatu perusahaan pialang berjangka atau broker, sedangkan yang melalui offline adalah bisa dilakukan melalui penukaran mata uang di bank-bank ataupun pada perusahaan money changer. Nilai Forex bersifat fluktuatif mengikuti perkembangan harga mata uang di dunia. Dengan rata-rata volume harian USD 5,3 Triliun tercatat pada bulan April 2013 yang lalu untuk seluruh dunia. Pasar Forex lebih kurang 46 kali lebih besar daripada semua gabungan pasar saham/modal dan arena itu disebut pasar paling liquid di dunia, buka selama 24 jam penuh secara berkesinambungan mulai hari Senin sampai Jum'at. Perdangangan Forex sering dikenal dengan istilah Trading, dan pelakunya disebut sebagai Trader/Pedagang. Para Pelaku Pasar Uang ini terdiri dari :

1. Bank Central (FED, Amerika; BOJ, Jepang; BoE , England / Inggris; ECB, Euro; BI, Indonesia, dan lain-lain)

2. Bank Komersial / Swasta, seperti BCA, AMRO, Mandiri, dan lain-lain.

3. Perusahaan Ekspor Impor, seperti Exxon, Xerox, General Motor, Nestle, dan lain-lain.

4. Pemerintah Suatu Negara. 
5. Broker / Perantara.

6. Pasar Bursa, BEJ (Bursa Efek Jakarta), BES (Bursa Efek Surabaya), Nasdaq (National Association of Securities Dealers Automated Quotations, Amerika), dan lain-lain.

7. Spekulan, dan

8. Individu/Retailer.

Ada sekitar Delapan jenis mata uang yang paling sering diperdagangkan yaitu: USD (Dollar Amerika), EUR (EURO, Mata uang gabungan Negara-negara di Eropa), JPY (Yen, Jepang), GBP (Poundsterling, Inggris), $\mathrm{CHF}$ (Swiss Franc), CAD (Dollar Canada), NZD (Dollar New Zealand) dan AUD (Dollar Australia) sering dikenal sebagai mata uang utama (Major). Sedangkan mata uang lain diluar itu, disebut sebagai mata uang kecil (Minor), seperti Dollar Hongkong, Singapura, Denmark, dan lain-lain. Dari perpasangan Mata Uang tersebut ada sekitar 20-an pasang mata uang yang sering/lazim dipasar forex, antara lain EURUSD, USDJPY, USDCAD, GBPUSD, USDCHF, dan seterusnya.

Pusat-pusat pasar forex dunia mendominasi sharing para trader di seluruh dunia. Inggris, Amerika Serikat, Singapura dan Jepang kini mempunyai andil $71 \%$ dari perdagangan forex di seluruh dunia atau meningkat dari $66 \%$ pada April 2010 lalu. Singapura, salah satu negara di Asia tenggara, telah menggeser Tokyo sebagai pusat trading forex ketiga terbesar di dunia setelah London dan New York. Pergeseran ini lebih disebabkan oleh beberapa faktor yang menunjang trading lebih kondusif seperti peraturan perdagangan finansial yang disesuaikan, kondisi ekonomi secara umum dan pemerintah yang mendukung bisnis ini.

Kenaikan volume transaksi per hari ini membuat pasar forex dan juga bisnis trading forex menjanjikan di masa yang akan datang. Perbaikan cara akses pasar dan transparansi terus terjadi. Perkembangan dunia komunikasi data dan teknologi informasi yang begitu cepat membuat jumlah trader retail bertambah dengan pesat. Bahkan institusi keuangan besar dan pemerintah juga telah menggunakan fasilitas internet untuk akses ke pasar forex.

Beberapa kelebihan dalam trading forex online dibandingkan dengan trading atau investasi lain adalah:

1. Likuiditas yang tinggi.

Kapanpun Anda ingin menjual, Anda boleh yakin bahwa akan selalu ada pembeli untuk itu. Intinya, hasil transaksi dapat segera dieksekusi dan keuntungan dapat segera direalisasikan. Hal ini tidak sama dengan pasar perdagangan saham ataupun jenis perdagangan portofolio yang lain. Secara skala pasar forex adalah yang terbesar, bahkan dibandingkan dengan bursa saham terbesar yang terkenal sekalipun seperti pasar saham Amerika / Nasdaq.

2. Peluang keuntungan dalam 2 (dua) arah.

Dalam trading forex baik saat pasangan mata uang melemah ataupun menguat kita bisa mendapatkan peluang profit. Dengan mengambil posisi buy, maka trader berharap mata uang akan menguat. Sebaliknya dengan posisi sell, maka trader 
berharap mata uang akan melemah, sehingga tidak perduli naik atau turun, trader tetap bisa meraup keuntungan. Market/Pasar Forex cenderung historikal/mengulang waktu yang telah lalu, dan hanya ada 3 gerakan grafik yaitu naik, turun dan sideway/datar.

3. Pasar forex buka 24 jam non stop, 5 hari seminggu.

Banyak pasar perdagangan di seluruh dunia yang terletak di lokasi dan tetap beroperasi dalam jam perdagangan yang ketat, sering terbatas hanya lima atau enam jam sehari di antara Senin dan Jumat. Namun pasar Forex buka 24 jam sehari, hanya hari Sabtu dan Minggu market tutup.

4. Adanya fasilitas leverage dalam perdagangan.

Sistem leverage (daya ungkit) inilah yang memungkinkan para trader dengan margin deposit yang terbatas dapat melakukan kontrak transaksi dengan jumlah besar. Hal ini memberikan kesempatan bagi para trader untuk memperoleh keuntungan berlipat. Anda dimungkinkan untuk bertransaksi dengan sistem margin trading dan bisa melakukan transaksi sebesar 10,000 unit hanya dengan 100 USD.

5. Teknologi Internet, trading dimanapun, kapanpun.

Sekarang hampir semua broker forex telah memanfaatkan internet agar semua orang sekarang bisa secara langsung memonitor, dan melakukan trading online lewat komputer, laptop, hp, ataupun gadget. Ini berarti dimanapun dan kapanpun Anda mau Anda bisa trading forex.

6. Trading dengan biaya rendah. Untuk dapat melakukan online forex trading, kita memerlukan jasa broker. Dan sekarang ini jumlah broker forex online sangat banyak sekali. Dan terkadang justru ini membuat kebingungan sendiri karena terlalu banyak pilihan. Namun, ada juga sisi positifnya. Yaitu, otomatis akan menimbulkan persaingan dari mereka untuk menawarkan biaya perdagangan yang murah sehingga memikat para kustomer untuk memilih mereka. Dan akhirnya: biaya perdagangan berupa fee/komisi dan sebagainya, bisa ditekan, bahkan untuk broker forex online ada yang bisa komisi nol.

7. Trading dengan modal sedikit.

Dulu kita mengenal bahwa untuk bisa trading forex diperlukan dana modal minimal puluhan ribu dollar. Tetapi sekarang tidak lagi, dengan modal $10 \$$ pun Anda sudah bisa trading forex. Hal ini dimungkinkan karena broker telah menyiapkan beragam jenis akun yang sesuai dengan kemampuan ekonomi kita. Seperti: akun standar, mini, dan yang paling kecil mikro.

8. Trading dengan dana virtual / demo

Ada lagi fasilitas dari broker berupa akun trading demo, dengan sistem ini kita dapat melakukan persis seperti trading forex yang sebenarnya, namun terlepas dari resiko kekalahan. Kok bisa? ya, karena dana yang digunakan adalah virtual/demo saja. Jadi 
kalau kalah tidak perlu mengganti uangnya, dan kalau menang juga tidak bisa diuangkan. Akun demo ini ditujukan untuk para pemula yang ingin berlatih dan belajar dulu sebelum terjun secara real ke dunia trading forex.

Bagi anda yang masih pemula dalam dunia forex, dan Anda bertanya tanya, Bagaimana bertansaksi di trading forex itu? Jawabannya adalah mudah sekali. Berikut ini adalah aturan dan cara trading Forex, yang antara lain:

1. Infrastruktur Forex

Sebelum masuk dalam tradingnya, kita jelaskan dulu mengenai infrastruktur penunjang. Untuk bisa trading forex online yang diperlukan hanya komputer PC, dan koneksi Internet. Ditambah dengan sebuah software aplikasi (MT4 /5/MetaTrader 4/5) yang bisa didownload dan digunakan secara gratis.

2. Dasar Dan Cara Trading Forex.

Pada dasarnya bertransaksi forex adalah memprediksi suatu pair mata uang bahwa nanti nilainya akan naik atau turun. Dan keyakinan dari prediksi itu kita wujudkan dalam membuka posisi trading (open position).

Dalam forex hanya ada 2 (dua) jenis open posisi. Yaitu :

1. BELI/BUY/LONG :

Memprediksikan nilai pair akan NAIK

2. JUAL/SELL/SHORT :

Memprediksikan nilai pair akan TURUN

Beberapa istilah dalam transaksi forex :

1. Pips atau Point

Pips adalah harga satuan unit terkecil dari mata uang apapun. Hampir semua pasangan mata uang memiliki lima digit angka. Dengan 1 digit pertama adalah angka pokok diikuti 4 digit angka pecahan(dibelakang koma). Sebagai contoh EUR / USD sama dengan 1.2420 dalam hal ini, satu pip sama dengan perubahan terkecil pada desimal keempat yaitu 0.0001, jadi jika pada pair dimana terdapat USD, maka satu pip selalu sama dengan 1/100 sen. Namun ada satu pengecualian saja yaitu pada USD/JPY, disini 1 pips bernilai $0.01 \$$

2. Bid Price

Bid price $=$ harga permintaan atau pembelian, adalah harga di mana pasar siap untuk membeli pasangan mata uang tertentu. Atau dengan kata lain bagi kita/trader adalah harga dimana kita dapat menjual. Misalnya, saat ini tertampil harga GBP/USD 1.8800 / 1.8803, maka $1.8800=$ bid price dan $1.8803=$ ask price. Jika saat ini anda berniat menjual GBP maka nilainya adalah 1.8800 .

3. Ask Price

Ask price $=$ harga penawaran atau penjualan, kebalikan dari bid price, maka ini berarti adalah harga dimana pasar siap untuk menjual mata uang tertentu, Atau bagi kita(trader) adalah harga dimana kita dapat membeli. Seperti contoh diatas GBP/USD 1.8800 / 1.8803, maka $1.8803=$ ask price, jika Anda berniat membeli GBP maka harganya adalah 1.8803 . 
4. Spread

Spread adalah selisih antara bid dan ask price. Harga bid selalu dan umumnya lebih kecil dari ask price. Mengikut contoh diatas GBP/USD 1.8800 / 1.8803, ini berarti spread adalah 3 pips.

5. Quote

Quote bisa dikatakan sebagai format penulisan yang umum di forex (baku) untuk menginformasikan pergerakan harga suatu pair tertentu. Formatnya adalah sebagi berikut :

Base currency/Second currency Bid price/Ask price sebagai contoh : GBP/USD 1.7750/1.7753, USD/JPY 84.90/84.94

6. Cross Currency

Mata uang cross adalah pair/pasangan mata uang di mana mata uang US tidak ada didalamnya. Sebagai contoh EUR/GBP, GBP/JPY. Semisal Anda membeli EUR/GBP = buy EUR/USD dan sell GBP/USD. Pada umumnya pair Cross sering membawa biaya transaksi yang lebih tinggi.

7. Margin

Margin adalah dana / saldo yang wajib tersedia, yang nantinya akan disisihkan oleh broker setiap kali Anda membuka / melakukan order baru. Berapakah besarnya margin? ini akan bergantung dari besarnya kontrak, leverage, lot.

Sebagai contoh, katakanlah Anda membuka rekening mini dengan leverage 200:1 atau $0,5 \%$. Dimana satu mini lot sama dengan $\$ 10.000$. Jika
Anda membuka transaksi sebesar satu lot, maka margin adalah $\$ 50(\$ 10.000 \times 0,5 \%$ $=\$ 50)$.

8. Leverage

Leverage adalah kemampuan untuk mengendalikan / bertransaksi dengan jumlah dollar yang besar dengan menggunakan jumlah modal yang relatif kecil. Dengan ratio yang biasa broker berikan adalah bervariasi dari 100:1 s/d 400:1.

Ilustrasi tentang leverage adalah: Semisal Anda memiliki uang tunai \$5.000 dalam rekening marjin dengan leverage 100:1, Anda bisa membeli sampai dengan $\$$ 500.000 senilai mata uang. Boleh dikata sekarang ini Anda memiliki $\$ 500.000$ daya beli.Dengan daya beli lebih, Anda dapat meningkatkan potensi keuntungan. Tapi sebaliknya ini juga sebanding dengan potensi kerusakan / kerugian yang akan Anda alami.

Margin + Leverage $=$ Kemungkinan Kombinasi Dari Potensi Yang Mematikan Jadi berhati-hatilah dalam memilih leverage.

9. Margin Call

Umumnya trader akan mulai merasa was-was dan takut ketika broker memberitahu bahwa sisa saldo/balance Anda telah mengecil jatuh dibawah tingkat minimum persyaratan, sebagai akibat posisi terbuka telah bergerak melawan Anda. Apabila posisi yang melawan (kerugian) ini sampai pada ambang batas yang ditentukan, maka broker 
akan menutup order (bisa sebagian / seluruhnya).

Dari beberapa informasi di atas dapat kita ketahui bahwa :

- Persyaratan/infrastruktur dalam trading forex online adalah sangat mudah dan murah.

- Dasar dari trading forex adalah sangat sederhana : Beli/Buy jika memprediksi akan naik, dan Jual/sell jika memprediksi akan turun. Dan jika prediksi benar maka akan memperoleh keuntungan, tetapi jika sebaliknya, resiko kerugian dapat kita minimalisasi dengan manajemen resiko yang baik, misalnya dengan terlebih dahulu mengetahui kekuatan ketahanan dana kita, pemakaian indikator untuk membantu memprediksi harga, dan lainlain.

- Infrastruktur, cara, dan aturan untuk bisa trading forex adalah mudah, cuma bagaimana cara trading yang benar agar bisa menjadi pemenang/memperoleh profit/keuntungan , itu yang perlu pengalaman dan latihan panjang.

\section{Profit Konsisten}

Bagaimana kita dapat memperoleh profit/keuntungan yang konsisten dalam perdagangan Forex ini? Ada beberapa hal yang perlu diperhatihan untuk menjawab pertanyaan tersebut, yaitu :

\section{Kita harus mempunyai}

TUJUAN dan TARGET yang jelas dan pasti.

Target dalam perhitungan yang optimal adalah antara $10-20 \%$ per bulan, artinya dengan taget seperti itu, ketahanan dana yang kita miliki masih relatif kuat bila terjadi salah posisi.
2. Kita harus mempunyai STRATEGI yang realistis dan teruji.

3. Kita harus mempunyai PSIKOLOGI TRADING yang benar.

Seorang trader harus memiliki psikologi trading, yaitu sifat dasar dan alami dalam berdagang, seperti sabar, disiplin dengan plan, mempunyai money management, tangguh dan tidak serakah.

\section{Analisis Pengambilan Keputusan Investasi}

Investasi adalah komitmen mengikatkan aset saat ini untuk beberapa periode waktu ke masa depan guna mendapatkan penghasilan yang mampu mengkompensasi pengorbanan investor berupa :

1. keterikatan aset pada waktu tertentu

2. tingkat inflasi dan

3. ketidaktentuan penghasilan pada masa mendatang.

Alternatif investasi, lahan investasi dibagi menjadi dua, yaitu real asset investment dan financial asset investment.

1. Real asset investment adalah komitmen mengikatkan aset pada sektor riil (sektor di luar keuangan). Ciri-cirinya :
a. Perantara tidak mutlak diperlukan
b. Informasi bisa dapat secara langsung
c. Obyek investasinya bisa dilihat secara nyata

2. Financial asset investment adalah investasi di sektor keuangan atau sering disebut juga portofolio investment (investasi portofolio) yaitu 
komitmen untuk mengikatkan aset pada surat-surat berharga (securities), yang diterbitkan oleh penerbitnya.

Ciri-cirinya:

a. Investasi perantara mutlak diperlukan

b. Informasi hanya didapat dari prospektus

c. Laporan tahunan atau proposal

d. Lebih banyak melibatkan profesi

e. Memiliki banyak medium.

Alternatif investasi Masa

Kini, dunia investasi keuangan tidak akan terlepas dari pengaruh teknologi dan informasi. Dari teknologi komunikasi, pengaruh akan datang dari dua sumber, yaitu dari hardware dan software. Dari hardware misalnya telepon selular(telepon genggam) yang bisa membantu perkembangan harga-harga sa-ham, obligasi maupun kurs mata uang. Dari software misalnya fasilitas software teleconference yang bisa mendapatkan nasihat informasi secara interaktif melalui internet.

Perdagangan forex (foreign exchange) yang di Indonesia dikenal sebagai perdagangan valas (valuta asing, intinya memperdagangkan mata uang asing). Di era modern ini, forex sudah mencapai forex online tranding. Maksudnya semua informasi dan eksekusi investasi bisa dilakukan melalui komputer yang terkoneksi dengan internet. Biaya investasi model ini jauh lebih murah dibanding cara investasi konvesional. Dengan demikian, forex online tranding telah menjadi trend masa alternatif investasi yang mudah dan murah di abad informasi ini.

Teknik memilih investasi, ada beberapa faktor yang harus dipertimbangkan dalam memilih investasi yaitu :
a. Modal
b. Tingkat pengembalian
c. Tingkat resiko
d. Arus dana
e. Biaya investasi
f. Informasi
g. Waktu perdagangan
h. Likuiditas pasar
i. Aktivitas pasar

\section{METODE ANALISA Metode Analisa dalam Pasar Uang}

Pasar uang yang dilakukan secara online melalui media internet, pada dasarnya adalah sebuah transaksi dagang yang membutuhkan skill/ketrampilan dan pengetahuan dalam menganalisa pergerakan harga dari mata uang, akan terjadi penurunan atau kenaikan harga. Kemampuan menganalisa pasar ini merupakan sebuah seni tersendiri bagi para pelakunya/trader. Setiap trader akan memiliki gaya/style masing-masing yang pasti berbedabeda, style/gaya trading yang saat ini berkembang setidaknya ada 3 gaya, yaitu

1. Scalping/trading jangka pendek, dengan mencari keuntungan sedikit tetapi relatif sering dalam transaksinya.

2. Intraday/trading harian, dengan gaya ini seoarang trader akan mengharapkan keuntungan secara harian dengan 1 atau 2 kali transaksi saja

3. Long Term/trading jangka panjang, trader dengan style ini mengarapkan keuntungan de- 
ngan transaksi jangka panjang/lebih dari satu hari untuk melakukan close posisi dengan target profit yang lebih besar dari dua model diatas.

Dalam bertrading akan berbeda-beda hasil yang akan dicapai oleh setiap trader, meskipun kita belajar bersama belum tentu hasilnya akan sama satu dengan yang lainnya. Skill/ketrampilan dan pengetahuan menganalisa sebuah pergerakan pasar uang merupakan kunci utama keberhasilan seorang trader. Analisa bisa dikatakan baik apabila profit yang dihasilkan selalu konsisten / terus menerus dan bertahan lama.

Secara garis besar ada 2 (dua) metode analisa yang digunakan untuk mengetahui pergerakan pada pasar uang, yaitu Analisa Teknikal dan Analisa Fundamental.

\section{Analisa Teknikal}

Analisa Teknikal adalah sebuah metode peramalan/estimasi pergerakan harga dengan melihat data historis harga yang terjadi pada pasar. Data harga adalah jenis data yang paling banyak digunakan dalam proses analisa, walaupun ada beberapa jenis data lain yang juga digunakan dalam proses analisa seperti volume dan open interest dalam kontrak futures.

Pada intinya ketika

menggunakan metode analisa teknikal apapun adalah kembali ke dasar teorinya, yang secara metodelogi telah terbukti kinerja untuk periode waktu yang signifikan. Setelah menemukan sebuah sistem trading yang sesuai, barulah bisa dicari teknik-teknik lain yang dapat digabungkan dengan metode trading yang sudah ada. Hampir semua trader menggunakan analisa teknikal walaupun jumlahnya minimum.
Bahkan pihak-pihak yang sangat mengacu pada analisa fundamental akan menggunakan atau melihat terlebih dahulu grafik harga sebelum melakukan transaksi.

Pada level teori yang sangat dasar, grafik membantu trader untuk menentukan level yang ideal untuk masuk pasar sebelum melakukan transaksi. Grafik menyediakan efek visual dari data historis pergerakan harga. Karenanya, trader dapat melihat grafik dan mengetahui apakah mereka membeli di harga yang wajar (berdasarkan data historis harga disebuah pasar tertentu), menjual di harga tertinggi periodik atau mungkin melakukan transaksi ketika pasar bergerak menyamping (sideways). Ini hanya beberapa kondisi pasar yang dapat di identifikasi oleh grafik. Grafik juga memungkinkan adanya analisa yang lebih canggih dan maju dari pergerakan harga.

Dalam prakteknya, mungkin seorang analisa teknikal mengesampingkan fundamental pasar dengan kesibukan dalam melihat grafik dan tabel data. Bagaimanapun, ini tergantung dari tipikal dari analis tersebut.

Asumsi Analisa Teknikal

1. Sejarah berulang dengan sendirinya dan karena itu pasar bergerak di kisaran yang dapat diprediksi, atau setidaknya memiliki pola tertentu. Pola-pola ini dihasilkan dari pergerakan harga, dinamakan sinyal. Tujuan analisa teknikal adalah untuk mendapatkan sinyal yang diberikan oleh kondisi pasar saat ini dengan mempelajari sinyal masa lalu.

2. Harga bergerak dalam bentuk tren. Analis teknikal biasanya tidak percaya bahwa fluktuasi 
harga bergerak dalam kondisi tidak terprediksi dan acak. Harga dapat bergerak dalam salah satu dari tiga bentuk arah, naik, turun, atau menyamping (sideways). Ketika sebuah tren terbentuk dari arah-arah pasar yang ada, biasanya akan berlanjut sampai beberapa periode.

Sistem dari analisa teknikal biasanya termasuk grafik harga, grafik volume, dan beberapa metode matematik lainnya dari pola dan perilaku pasar. Metode manipulasi matematik dari bermacam-macam jenis data pasar ini digunakan untuk menentukan kekuatan dan ketahanan dari tren tertentu. Jadi analis teknikal cenderung untuk menggunakan berbagai bentuk analisis teknikal sebelum melakukan transaksi daripada hanya mengandalkan grafik harga untuk mengestimasi nilai pasar di masa datang.

Sama halnya dengan aspek lain dari trading, dalam penggunaan analisa teknikal harus disiplin. Seringkali seorang trader gagal melakukan transaksi, membeli atau menjual, ketika harga telah mencapai pola teknikal yang diidentifikasi sebagai sinyal masuk atau keluar pasar.

Ada banyak faktor lainnya yang berpengaruh terhadap hal ini seperti teknologi, fundamental dan lain sebagainya. Kesalahan umum yang sering dibuat oleh para trader adalah mengharapkan harga akan berbalik arah terhadap posisi yang merugi dan terlalu cepat melikuidasi posisi yang sedang mengalami keuntungan. Dibutuhkan kedisiplinan tinggi dalam penggunaan analisa teknikal.

Grafik Harga
1. Bentuk Grafik Batang Terdapat banyak jenis grafik yang menunjukkan pergerakan harga, yang paling umum digunakan adalah grafik batang (bar chart). Tiap batang (bar) menandakan pergerakan harga di satu periode tertentu, satu menit, satu hari, atau satu bulan. Pergerakan harga dalam bentuk batangbatang ini akan membuat polapola tertentu pada suatu periode.

2. Bentuk Candlestick Seperti grafik batang, pola candlestick dapat digunakan untuk memprediksi pasar. Karena bentuknya memiliki warna, candlestick lebih memiliki efek visual dalam polanya daripada grafik batang.

3. Bentuk poin \& figur Pola dalam bentuk ini sebenarnya sama dengan pola yang dihasilkan oleh grafik batang namun poin \& figur tidak menggunakan skala waktu untuk mengindikasikan hari tertentu yang berhubungan dengan pergerakan harga tertentu.

\section{Indikator Teknikal}

Dibawah ini adalah beberapa tipe indikator yang sering digunakan oleh para trader dalam analisa teknikal.

1. Indikator Trend ialah sebuah kata yang menggambarkan adanya pergerakan satu arah yang kuat di untuk beberapa waktu ke depan. Trend bergerak dalam 3 arah: naik, turun, dan menyamping. Indikator trend menghaluskan data harga yang bervariasi untuk menciptakan komposisi arah pasar. (contoh: Moving Average).

2. Indikator Kekuatan pasar menggambarkan intensitas dari 
opini pasar yang berhubungan dengan sebuah harga dengan melihat posisi pasar yang diambil oleh beragam pelaku pasar. Volume atau open interest adalah bahan dasar untuk indikator ini. Sinyal yang diberikan sifatnya coincident atau leading. (contoh: Volume)

3. Indikator Volatilitas. Indikator volatilitas adalah istilah umum yang digunakan untuk menggambarkan kekuatan pergerakan, atau ukuran, dari fluktuasi harga harian terpisah dari arahnya. Umumnya, perubahan pada volatilitas cenderung mempengaruhi perubahan harga. (contoh: Bollinger Band)

4. Indikator Support/Resistance Support resistance menggambarkan level harga dari kenaikan dan penurunan berulang dan kemudian berbalik arah. (contoh: Trend Lines)

5. Indikator Momentum ialah istilah umum untuk menggambarkan kecepatan pergerakan harga di periode tertentu. Indikator momentum menentukan kekuatan atau kelemahan dari sebuah tren. Momentum berada tertinggi ketika mulainya sebuah trend dan terendah pada saat perubahan arah. Divergence arah apapun dari harga dan momentum mengindikasikan pergerakan telah melemah. Jika terjadi pergerakan harga ekstrim dengan momentum yang lemah, hal itu merupakan sinyal dari akhir pergerakan di arah tersebut. Jika momentum bergerak trend dengan kuat dan harga bergerak datar, hal itu memberikan sinyal adanya potensi perubahan arah harga. (contoh: RSI, Stochastic, $M A C D)$.

\section{Analisa Fundamental}

Analisa Fundamental adalah analisis yang didasarkan pada situasi dan kondisi ekonomi, politik dan keamanan secara global dan juga tiap-tiap negara yang mengeluarkan Index Saham.

Analisa fundamental membutuhkan kelihaian seni tersendiri untuk memperhitungkan penting tidaknya suatu informasi menjadi faktor yang akan berpengaruh terhadap fluktuasi nilai tukar suatu mata uang.

Berikut adalah prinsipprinsip analisis fundamental :

a) Reaksi Berantai : Semakin besar dampak berantai suatu informasi, maka akan semakin besar pengaruhnya terhadap nilai sebuah index perusahaan.

b) Jarak Informasi : Semakin dekat sebuah informasi dengan suatu index saham, maka akan semakin besar pengaruh informasi tersebut. Misalnya, informasi yang berasal dari dalam negeri Indonesia akan besar pengaruhnya terhadap nilai IHSG dibandingkan informasi dari luar negeri.

c) Sumber Berita : Semakin resmi sumber berita tersebut, maka akan semakin kuat pengaruhnya terhadap nilai suatu index saham.

d) Jenis Berita : Berita ekonomi lebih kuat pengaruhnya terhadap index saham suatu negara dibanding berita lainnya, seperti politik, sosial maupun budaya.

Segala informasi hingga hal-hal yang tidak rasional harus dikumpulkan, guna dijadikan alat 
untuk memprediksi pergerakan suatu index saham ataupun pasar uang/forex. Pada intinya, informasi tersebut akan mempengaruhi supply dan demand atas index saham/mata uang suatu negara.

Dalam melakukan metode analisis fundamental adalah dengan terus-menerus mengupdate informasi yang ada. Mengenai media informasi tersebut tergantung, ketersediaan yang ada di tempat kita. Namun untuk trading index saham/forex, informasi ini akan selalu tersedia.
Sifat Berita Fundamental dapat dikelompokkan menjadi 2, yaitu:

1. Berita Permintaan Bersifat Bullish.

Bullish berasal dari kata 'bull' (sapi jantan), sifat tersebut menggambarkan gerakan harga pasar terlihat seolah-olah akan turun namun sebenarnya akan naik (mirip gerakan sapi jantan menanduk musuhnya yaitu, menanduk kemudian dilemparkan keatas).

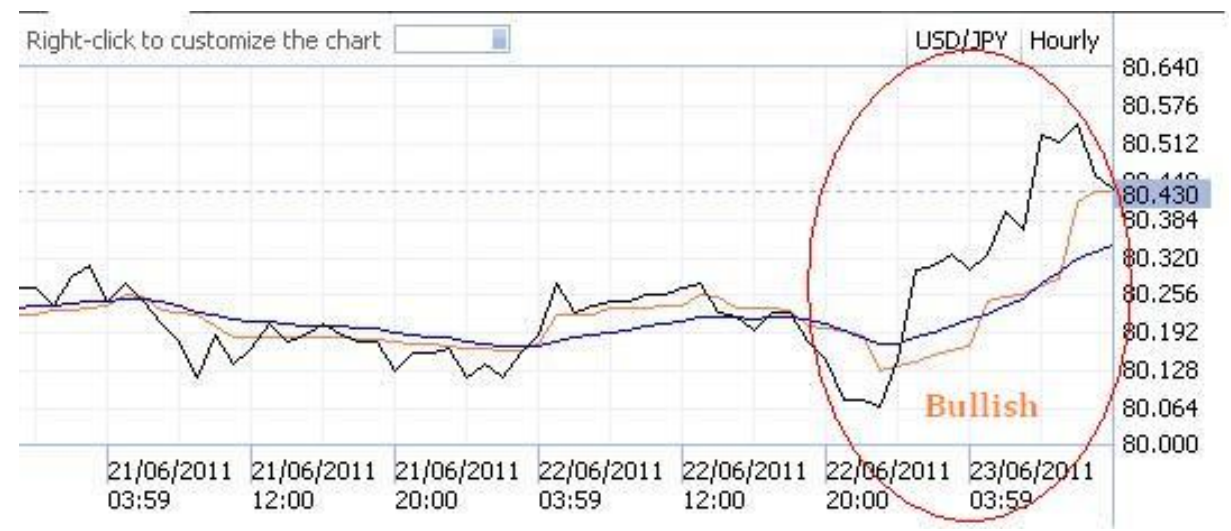

2. Berita Penawaran / Supply bersifat BEARISH

akan naik namun sebenarnya Bearish berasal dari kata 'bear' (beruang), sifat tersebut menggambarkan gerakan harga pasar yang terlihat seolah-olah harga akan turun (mirip gerakan beruang mencengkeram mangsanya, yaitu mengangkat lalu dibanting).

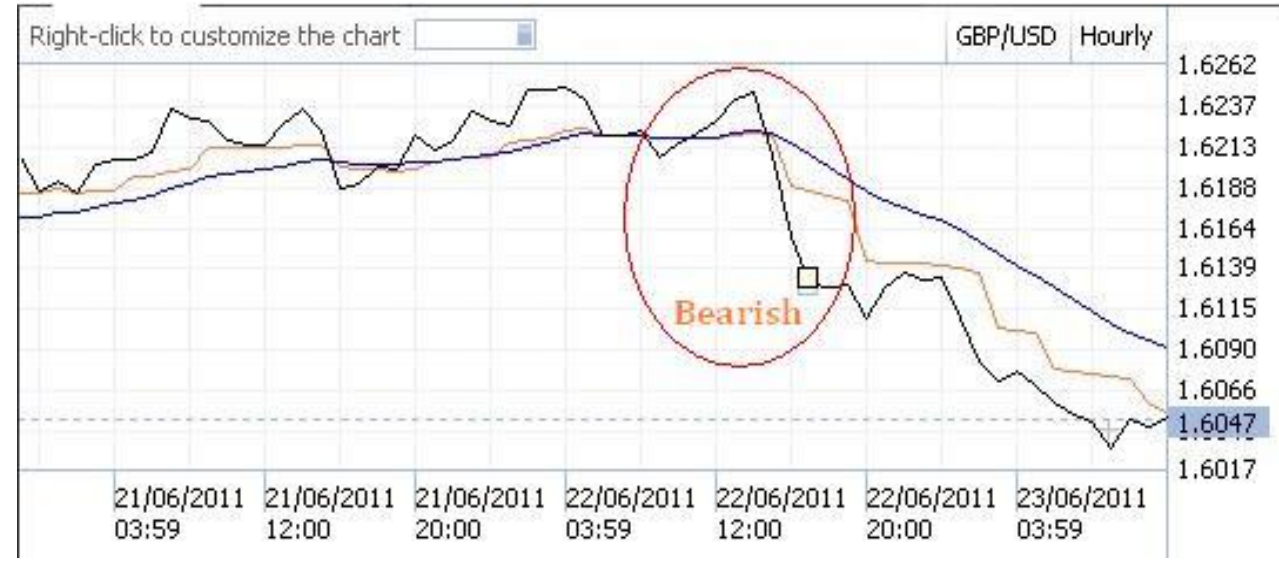

Keuntungan Analisa Fundamental

1. Dapat menentukan harga secara global. 
2. Pada kasus tertentu efektif untuk short term trading.

3. Penentu trend jangka panjang (long term).

Kelemahan Analisa Fundamental

1. Tidak bisa menentukan secara cepat.

2. Memakan banyak waktu.

3. Subyektif, terlalu banyak asumsi dan sumber yang dipakai.

\section{KESIMPULAN}

Dari hasil penelitian ilmiah ini dapat disimpulkan bahwa pengambilan keputusan yang baik dalam investasi untuk mendapatkan profit yang konsistenpada perdagangan dipasar uang online internetharus didasarkan pada pengetahuan tentang pasar uang online dengan penggunakan analisa teknikal maupun fundamental serta money management dan psikologi trading yang sesuai dengan tujuan dan target dalam investasi ini.

Perdagangan mata uang asing tidak ada bedanya dengan barang lainnya, yaitu terjadi aktivitas pertukaran, dimana pemilik barang menyerahkan barangnya kepada pembeli.Contohnya bila di Indonesia memiliki mata uang rupiah lalu kita ingin membeli dollar AS maka kita menyerahkan rupiah kita untuk mendapatkan dollar AS. Tentu nilai pertukaran tersebut menurut harga pasar.

Beberapa keuntungan dari Perdagangan forex online :

1. Investasi murah

2. Dealing rate (mempermudah melihat jenis mata uang yang diperdagangkan)

3. Trader order (untuk mengorder posisi harga $B U Y / S E L L)$

4. Tingkat leverage

5. Tingkat likuiditas
6. Waktu perdagangan

7. Free real time quotes

8. Guaranteed limited risk, adanya garansi atas batasan risiko yang akan dialami oleh investor

Dengan pemanfaatan teknologi online internet, dalam mengembangkan investasi keuangan yang kita miliki, trading mata uang online adalah salah satu alternatif pilihan yang sangat menguntungkan dan bermanfaat bagi semua kalangan, khususnya untuk membantu pemerintah dalam mengurangi tingkat penggangguran terdidik saat ini. Dan melalui pelatihan yang dilakukan oleh Lembaga Pendidikan dan Pelatihan Kerja (LPPK) Financial Education Nganjuk, yang berusaha membantu dalam memberikan pelatihan kerja trading online internet ini bagi semua saja yang ingin mendapatkan penghasilan, baik sebagai pokok ataupun sebagai tambahan untuk membantu perekonomian keluarga.

\section{Daftar Pustaka}

Tier Mark (2011), The Winning Investment of Warren Buffett and George Soros ; Pelajaran yang bisa anda terapkan dari dua investor terkaya didunia , Jakarta, BIP, Kelompok Gramedia.

Hendarto Kusumarsono (2012), Belajar Trading, Pahami Trading sebelum Memulai, Semarang, Rajawali press.

Prawira Budi T (2008), Revolusi Investasi di Era Cyber, Yogyakarta, Cemerlang Publishing 
